\title{
Enhancing Undergraduate Students Subject's Understanding through Fieldwork
}

\author{
Elie F. Itoba - Tombo ${ }^{1,2}$, Bonita Kleyn-Magolie ${ }^{1}$, Andrew Rand ${ }^{1}$, Vincent Zungu ${ }^{1}$ and John Baptist \\ Mudumbi ${ }^{1,2}$
}

\begin{abstract}
Fieldwork is known as a practical/physical way of teaching and learning. Thus, fieldwork is a complementary learning opportunity for students to participate in order to augment their theoretical learning. This research investigated the effectiveness of fieldwork as a tool to enhance the understanding of the Environmental Geology subject for the first year students in the Extended Curriculum Programme (ECP) at Cape Peninsula University of Technology in 2018. There were $(n=39)$ students in the first year class. During the first semester, the students were exposed to theoretical learning only while, during the second semester, practical learning (fieldwork) was included to support theoretical learning. The results revealed a failure rate of $53 \%$ in the first semester. However, during the second semester the students' performance improved after exposure to fieldwork, which culminated in a pass rate of $76.7 \%$. Therefore, the study concluded that fieldwork was critical in enhancing the students understanding, knowledge as well as skills and contributed enormously in improving the subject's pass rate.
\end{abstract}

Keywords - Environmental Science, Environmental Geology, Effectiveness teaching, Fieldwork, Theoretical teaching.

\section{INTRODUCTION}

Many tertiary institutions around the world and in South Africa in particular receive a high number of first year students yearly that are willing to become scientists after completing their studies. Sometimes these aspiring scientists experience challenges such as adaptating to a new university environment, the style of teaching and learning etc., which might affect the student's understanding of the subject's or course curriculum , contributing to the high failure and drop out rates. Thus, to avoid such issues, fieldwork can be envisaged as a way to enhance the students understanding of the subject knowledge. Many scientists (i.e. Geographers, Geologists, Psychologists, Environmental scientists) etc., emphasized a positive role of fieldwork in students learning [1]. [1] believes that fieldwork offers students many pedagogical benefits. Thus, fieldwork is paramount for the training of students as it requires them to use and develop or strengthen their cognitive and affective skills [2]. Its enable students to make personal observations, inquiries, interpretations, re-interpretations based on the theory, lab-work and natural aspects on the field [3]-[5]. It helps to demonstrate the validity of the theory. A subject such as

1. Department of Environmental and Occupational Studies, Cape Peninsula University of Technology, P.O. Box 652, Cape Town, 8000, South Africa,

2. Bioresource Engineering Research Group (BioERG), Department of Biotechnology, Cape Peninsula University of Technology, P.O. Box 652, Cape Town 8000, South Africa;
Environmental Geology for example, require students to not only grasp the theoretical teaching of aspects, processes etc., but also to be able to touch, identify, observe, interpret/explain the occurrence of those aspects, processes (or events) in the natural environment. As suggested by [6]-[10]. Therefore, fieldwork becomes indispensable for these students to physically see, observe, analyze, interpret/explain the practicality of the theory, to which they were subjected to during the teaching and learning process.

Previously, students from higher education institutions have used fieldwork application and/or practical for subjects such as Geographical Information Systems (GIS), Geography, Geohydrology, etc., coupled with mobile devices [1], [11], [12 ]. However, to our knowledge there is little scientific evidence on the importance of fieldwork for a subject such as Environmental geology

Thus, it is necessary that such a study be undertaken to add to the existing scientific literature and demonstrates the importance of fieldwork in improving students' understanding of the subject.

\section{MATERIAL AND METHODS}

In this 2018 study, a class of $(n=39)$ first year students in the Extended Curriculum Programme (ECP) at the Cape Peninsula University of Technology were used to assess the effectiveness of fieldwork as a tool to enhance the understanding of the subject, Environmental Geology. An academic year consists of two semesters. During the first semester, the students were exposed to theoretical learning only whereas, during the second semester, practical learning (fieldwork) work was implemented as an additional teaching and learning method to supplement the theoretical teaching.

The objective of the study was to assess the students' understanding of the concepts/processes taught in class. Thus, the students were taken to the field and were exposed to concepts such as weathering, erosion, stratification, etc. The students were given a brief talk about each process followed by a practical identification of the processes (i.e. weathering, erosion) in the field. The students observed, touched, analyzed and identified the types of weathering, erosion etc., their characteristics,effects on the geological material (rocks), field and the environment. The students were also able to observe the stratification (layering/bedding) process of geological material. The duration of the outing was $3-4 \mathrm{hrs}$, and the students were asked to draft a field report as part of an assessment. 


\section{RESULTS}

\section{A. Results Analysis}

A comparison of the two semesters results, shows that during the first semester the students struggled to comprehend most of the concepts and aspects taught in class. Thus, during the first semester out $(n=39)$ total registered students, $n=21$ passed their assessments (53\%), $n=13$ failed and $n=2$ dropped out (refer Figure 1). Whereas, after the introduction of fieldwork during the second semester, the student's marks drastically improved. Thus, $n=30$ out of $n=39$ the equivalent of $(76.9 \%)$ passed the subjects, $n=4$ failed and $n=2$ dropped out. Fieldwork provided the students with a a great opportunity to strengthen their understanding and knowledge of Environmental Geology. The results of this study confirm those of previous studies by [1]-[7]; [9] and [10].

\section{SEMESTER 1 RESULTS}

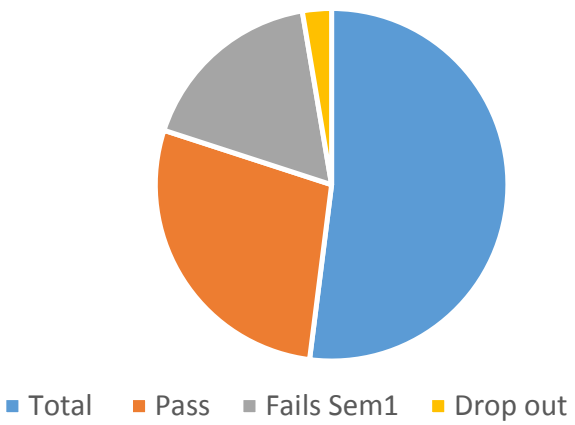

Fig. 1. Semester 1 results

\section{SEMESTER 2: END OF THE YEAR} RESULTS

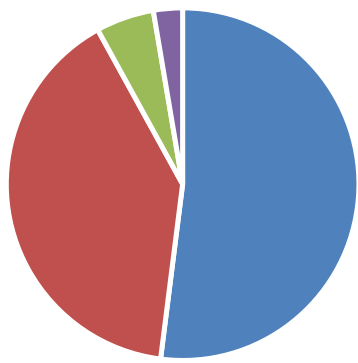

- Total - Pass - Fails Sem2 - Drop out

Fig. 2. Semester 2 results
Fieldwork creates a feeling of enjoyment for the students, as they are taken out of the classroom to experience nature physically. A Fieldwork creates a positive learning environment that help to deepen the students learning. Previous studies demonstrated that fieldwork creates enjoyable moments that will yield deep learning [1], [7], [9], [10].

\section{B. Students opinions of the fieldwork}

The students were asked to complete a fieldtrip feedback form. Below are a few of the students' responses,

- "It was a very educational outing where we can see and touch material, aspects taught in the classrooms."

"This excursion has answered many of the questions we had as Environmental Geology students."

- $\quad$ "It made the module/course more interesting, because we got to deal with real world aspects that we normally discuss in class."

- "I can say, that it was a practical experience of the theory we were taught in the classroom."

\section{CONCLUSION}

In conclusion, fieldwork was paramount in improving the first year students understanding, practical skills and theoretical knowledge of Environmental Geology and contributed immensely in enhancing the subject's pass rate.

\section{ACKNOWLEDGMENT}

I would like to express my gratitude to the Department of Environmental and Occupational Studies and the Faculty Applied Sciences' Extended Curriculum management at the Cape Peninsula University of Technology, for the organization and all logistical issues, which contributed to a successful fieldtrip.

\section{REFERENCES}

[1] Hope M . 2009. The Importance of Direct Experience: A Philosophical Defence of Fieldwork in Human Geography. Journal of Geography in Higher Education, Vol. 33, No. 2, 169-182, May 2009 https://doi.org/10.1080/03098260802276698

[2] Kestens, K., Manduca, C. A., Cervato, C., Frodeman, R., Goodwin, C., Lieben, L.S., Mogk, D. W., Spangler, T.C., Stillings, N.A., and Titus, S. 2009. How Geoscientists Think and Learn. GSA Special Paper. Eos Trans. AGU, 90(31), 265 https://doi.org/10.1029/2009EO310001

[3] Kestens, K., Manduca, C. A. 2012. Earth and Mind II: A synthesis of Research on Thinking and Learning in the Geosciences. Ed. K. Kastens. GSA Special Paper 484 (ISBN: 9780813724867) https://doi.org/10.1130/SPE486

[4] Frodeman, R.., 2003. Geo- Logic: Breaking ground between philosophy and the Earth sciences, 184, SUNY Press, Albany, New York, Mossa, J. 1995.

[5] Mossa, J. 1995. Participatory student field guides and excursions. Journal of Geography in Higher Education 19(1):83-90 https://doi.org/10.1080/03098269508709290

[6] 6. Kennedy, T. \& Waddington, S. (2003) Examining the effects of teaching/learning methods on student understanding of value-laden issues, Planet, Special Issue 5, pp. 65-67.The Importance of Direct Experience 181 
[7] Kent, M., Gilbertson, D. D. \& Hunt, C. O. (1997) Fieldwork in geography teaching: a critical review of the literature and approaches, Journal of Geography in Higher Education, 21(3), pp. 313-332. https://doi.org/10.1080/03098269708725439

[8] Healey, M. \& Jenkins, A. (2000) Kolb's experiential learning theory and its application in geography in higher education, Journal of Geography, 99, pp. 185-195. https://doi.org/10.1080/00221340008978967

[9] Boyle, A., Conchie, S., Maguire, S., Martin, A., Milson, C., Nash, R., Rawlinson, S., Turner, A. \& Wurthmann (2003) Fieldwork is good? The student experience of field courses, Planet, Special Issue 5, pp. 48-51.

[10] Boyle, A., Maguire, S., Martin, A., Milsom, C., Nash, R., Rawlison, S., Turner, A., Wurthman, S. \& Conchie, S. (2007) Fieldwork is good: the student perception and the affective domain, Journal of Geography in Higher Education, 31(2), pp. 299-317. https://doi.org/10.1080/03098260601063628

[11] Krull, G., \& Duart, J. M. (2017). Research Trends in Mobile Learning in Higher Education: A Systematic Review of Articles (2011 - 2015). The International Review of Research in Open and Distributed Learning, 18(7). https://doi.org/10.19173/irrodl.v18i7.2893

[12] A. Lynn Stephens , Amy Pallant and Cynthia McIntyre. 2016. Telepresence-enabled remote fieldwork: undergraduate research in the deep sea. INTERNATIONAL JOURNAL OF SCIENCE EDUCATION, 2016 VOL. 38, NO. 13, 2096-2113 http://dx.doi.org/10.1080/09500693.2016.1228128

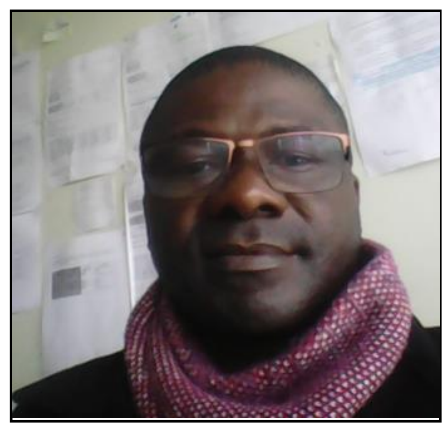

Elie F. Itoba-Tombo

PhD-Environmental Studies (Environmental Health)- Cape Peninsula University of TechnologyRSA

-Master's (MTech) Environmental Management-2010.Cape Peninsula University of Technology RSA BSc Honours- Earth Environmental Sciences- 2004- University of the Western Cape-, RSA Bachelor (BSc) Option: Physical Geography- 1996 - University of Brazz (Marien Ngouabi)- Republic of Congo Currently working as a lecturer of Ecology, Environmental Geology,

Enviornmental Management IV and Environmrntal Economics V) in the Department of Environmental and Occupational Studies-

Environmental Management Programme; from 2007 to Present

\section{Publications:}

Books chapters:

Elie Ferche Itoba-Tombo, Abraham Thomas, Stam M. Ed. 2019. Spatial and temporal distribution of pollutants from different land-use/land-cover types of the Bottelary River catchment. In New Horizons in Wastewaters Management: Emerging Monitoring and Remediation Strategies. Prof. Dr. Elvis Fosso-Kankeu (Ed.). Nova Science Publishers,Inc. (NOVA), ISBN: 978-1-53615-659-1

E. F. Itoba Tombo, S.K.O. Ntwampe and J. B. N. Mudumbi, 2017. Leaching of cyanogens and mycotoxins from cultivated Cassava into agricultural soil: Effects on groundwater quality. in Aflatoxin -Control, Analysis, Detection and Health Risks, Dr. Lukman Bola Abdulra'uf (Ed.), InTech, ISBN: 978-953-51-5464-

journal articles/conference papers/data journals:

Aphelele Tomsana, Elie Fereche Itoba- Tombo, Izanne Susan Human. 2020. An analysis of environmental obligations and liabilities of an electricity distribution company to improve sustainable development. SN Applied Sciences. 2:1648; https://doi.org/10.1007/s42452-020- 03462-y.

Justine O. Angadam, Nkosikho Dlangamandla, Seteno K. O. Ntwampe,* Elie F. Itoba Tombo, and Boredi S. Chidi. 2019. Sustainable Nepenthes mirabilis Facilitated Recovery of Reducing Sugars from Grape Pomace. BioResources, 14(2): 3944-3960, DOI: 10.15376/biores. 14.2.3944-3960

John Baptist Nzukizi Mudumbi, Adegbenro Peter Daso, Okechukwu Jonathan Okonkwo, Seteno Karabo Obed Ntwampe, Tandi E. Matsha, Lukhanyo Mekuto ,Elie Fereche Itoba-Tombo, Adewole T. Adetunji and Linda L.
Sibali. 2019. Propensity of Tagetes erecta L., a Medicinal Plant Commonly Used in Diabetes Management, to Accumulate Perfluoroalkyl Substances. Toxics 2019, 7 (18); doi:10.3390/toxics7010018

E. F. Itoba-Tombo, Seteno Karabo Obed Ntwampe, John Baptist Nzukizi Mudumbi, Lukhanyo, Mekuto, Enoch Akinbiyi, Akinpelu and Ogheneoc] 2018. Rapid Identification of Cunninghamella bertholletiae's Toxins/Sec via a Fermentation Technique. 10th International Conference on Advance Science, Engineering, Technology and Healthcare (ASETH-18); Nov. 19 Cape Town, South Africa doi.org/10.17758/EARES4.EAP1118110.

N. Dlangamandla, S.K.O. Ntwampe, J.O. Angadam, E.F. Itoba-Tombo and B 2018. Production of Low (C 1 to C 3 ) and High Carbon Content (C $4+$ ) Aerobic Conditions Using Total Reducing Sugar from Mixed Agro-Waste. 10th International Conference on Advances in Science, Engineering, Technology and Healthcare (ASETH-18); Nov. 19 Cape Town, South Africa. doi.org/10.17758/EARES4.EAP1118256.

Lionnel A. N. NDEBA NGANONGO, Seteno K.O. Ntwampe, S. Szabolcs and E.F. Itoba-Tombo, 2018. The Application of ADM/ASM Interface in S Model. 10th International Conference on Advances in Science, Engineeri and Healthcare (ASETH-18); Nov. 19-20, 2018 at Cape Town, South Africa DOI: https://doi.org/10.17758/EARES4.EAP1118257.

L. Mekuto, Y.M. Kim, S.K.O. Ntwampe, M. Mewa-Ngongang, J.N. Mudumbi Dlangamandla, E.F. Itoba-Tombo, E.A. Akinpelu, 2018. Heterotrophic denitrification potential of cyanide and thiocyanate degrading microbial c cyanogenic conditions. Environmental Engineering Research. doi.org/10.

John Mudumbi, Seteno Karabo Obed Ntwampe, Lukhanyo Mekuto, Tandi E. I Elie Fereche Itoba-Tombo. 2018. The role of pollutants in Type 2 Diabr (T2DM) and their prospective impact on phytomedicinal treatment strate; Environmental Monitoring and Assessment. https://doi.org/10.1007/s106

Mekuto L., Kim Y. M., Ntwampe S. K. O., Mewa-Ngongang M.,Mudumbi J.B Dlangamandla N., Itoba-Tombo E. F. 2018. Heterotrophic NitrificationDenitrification Potential of Cyanide and Thiocyanate Degrading Microbi: Communities under Cyanogenic Conditions. Section: SEWAGE MANAr AND TREATMENT. 10th Eastern European Young Water Professionals IWA YWP, 7-12 May 2018, Zagreb, Croatia. Pp. 243 - 244. ISBN: 978-!

John Baptist Nzukizi Mudumbi, Seteno Karabo Obed Ntwampe, Lukhanyo Me Elie Fereche Itoba-Tombo, Tandi E. Matsha, 2017, Are aquaporins (AC Gateway that conduits nutrients, persistent organic pollutants and perfluo substances (PFASs) into plants? Springer Science Reviews, 5(1-2), pp. 3

John Baptist Nzukizi Mudumbi, Seteno Karabo Obed Ntwampe, Tandi Matsha Lukhanyo Mekuto, Elie Fereche Itoba-Tombo. 2017. Recent developm Polyfluoroalkyl compounds research: A focus on human/environmental $\mathrm{h}$ impact, suggested substitutes and removal strategies. Environmental Mon Assessment, 189(8), p.402.

Itoba-Tombo, E.F., Obed Ntwampe, S.K., Bell, J.J.A., Nzukizi Mudumbi, J.B Mhlangabezi Golela, T., 2017. A decade's (2014-2024) perspective on ci (Manihot esculenta crantz) contribution to the global hydrogen cyanide ls environment. International Journal of Environmental Studies, 74(1), pp.2 